\title{
RESERVOIR QUALITY OF SANDSTONES IN THE NAKNEK AND KAGUYAK FORMATIONS: FIELD OBSERVATIONS
}

by Kenneth P. Helmold ${ }^{1}$

During the 2012 Cook Inlet field season we spent seven days (July 14-20) on the Iniskin Peninsula examining outcrops of the Naknek Formation. Twelve additional days (July 24-August 4) were spent in the Katmai-Cape Douglas area surveying outcrops and measuring sections of the Kaguyak and Naknek Formations.

\section{Naknek Formation}

Naknek Formation sandstones on the Iniskin Peninsula are very feldspathic, consisting of 40-70 percent (average 50 percent) calcic-plagioclase, with 0-20 percent (average 10 percent) monocrystalline quartz, 5-20 percent (average 15 percent) volcanic rock fragments (VRFs), and 2-45 percent (average 20 percent) accessory detrital minerals, predominantly hornblende, magnetite/ilmenite, and micas. This combination of abundant plagioclase and minor quartz results in a labile framework mineralogy that is highly susceptible to diagenetic alteration. Based on petrographic examinations of previously collected outcrop samples, laumontite is the dominant cement in the majority of samples. It occurs as a replacement of detrital plagioclase grains and as intergranular cement that occludes all primary porosity. In samples containing a higher proportion of VRFs, heulandite cement occurs in addition to, or instead of, laumontite. In either case, primary porosity is almost totally destroyed. Some of the massive sandstone intervals (fig. 10A) display a distinct color zonation with alternations of white- and brown-colored laminae (fig. 10B). My initial hypothesis, based solely on hand lens observations, is that the "white" laminae contain few VRFS and are largely cemented by laumontite, while the "brown" laminae contain a higher proportion of VRFs and are cemented by heulandite. Several samples were collected to test this hypothesis (fig. 10B); they will be plugged for routine core analysis with the plug ends allocated to thin sections. Because of the extensive cementation, Naknek sandstones on the Iniskin Peninsula probably have low potential as conventional reservoirs. If migration of hydrocarbon occurred prior to cementation, it is still feasible that primary porosity may be retained locally, but this was not observed during our field reconnaissance. However, the Naknek in this area is highly fractured and could have potential as an unconventional fractured reservoir (see Gillis and others, this report).

Sandstones of the Naknek Formation were examined in the vicinity of Katmai-Cape Douglas along the southern shore of Kamishak Bay. One stratigraphic section was measured near the mouth of the Douglas River along the southern coast of a small, unnamed island (figs. 1 and 11A; see also Stanley and others [Observations from a hydrocarbon-bearing sandstone in the Naknek Formation], this report). We specifically targeted this outcrop because of previous USGS reports of the existence of a hydrocarbon seep. Based solely on hand-lens observations, this sandstone consists of greater than 50 percent quartz and K-feldspar, with a lesser quantity of plagioclase and heavy minerals. In that respect it has a much

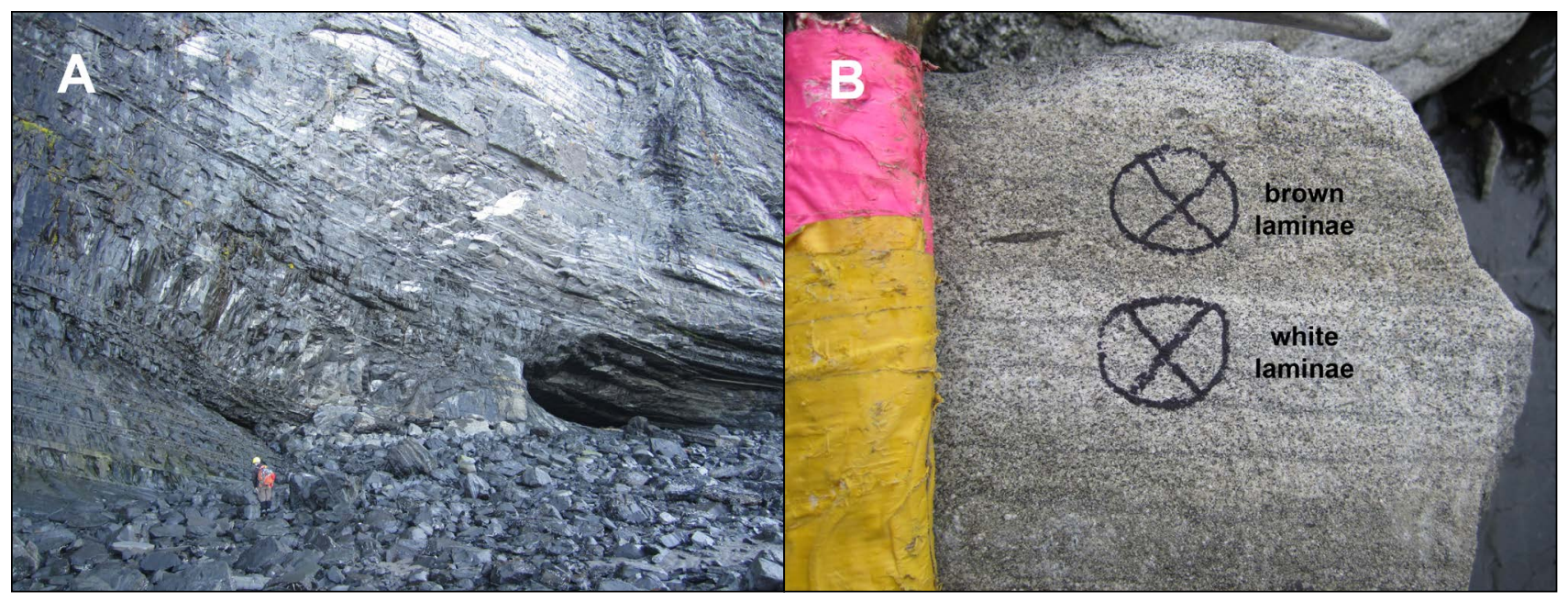

Figure 10. (A) Vertical cliffs of Pomeroy Arkose Member of Naknek Formation exposed along the eastern shore of Oil Bay on the Iniskin Peninsula. (B) Pomeroy arkose with alternating white- and brown-colored laminae that possibly reflect differences in detrital composition (VRF content) and cementation (laumontite versus heulandite).

${ }^{1}$ Alaska Division of Oil \& Gas, 550 W. 7th Ave., Suite 800, Anchorage, AK 99501-3560 


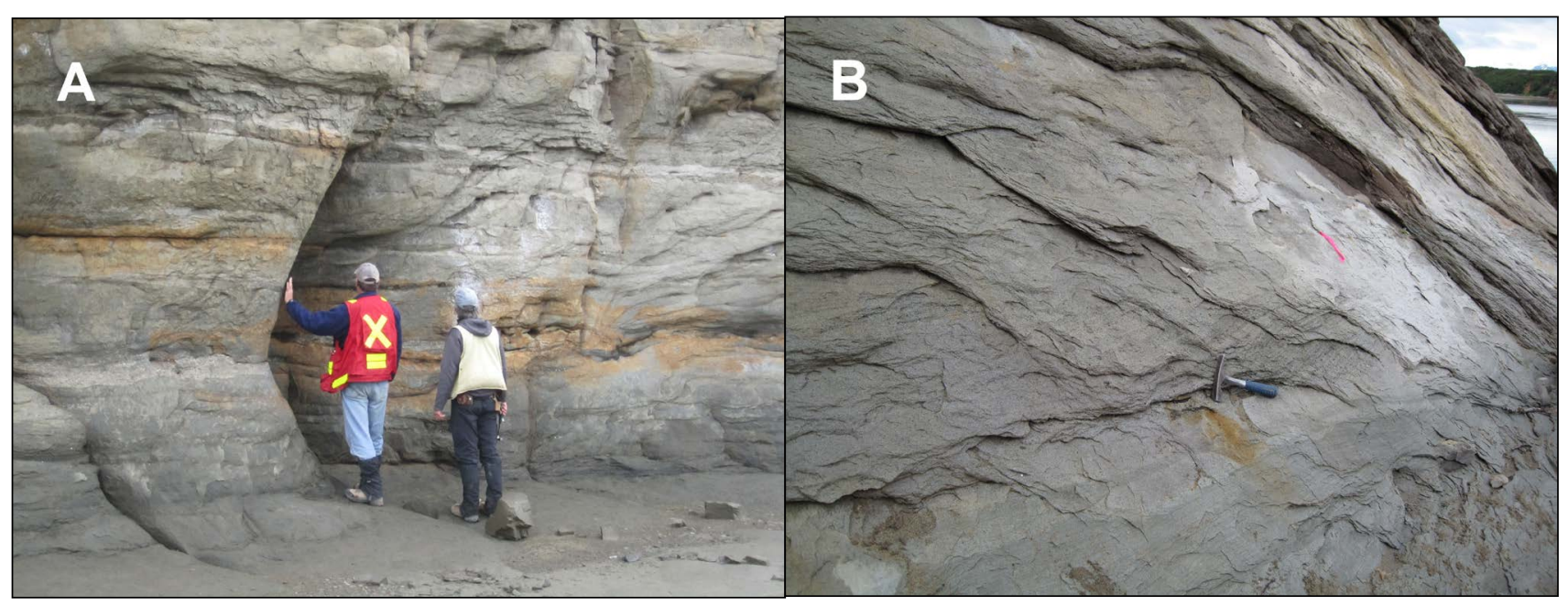

Figure 11. (A) Outcrop of Indecision Creek Sandstone Member of Naknek Formation exposed along the southern shore of Douglas Island. (B) Hydrocarbon-stained sandstone with a compositionally mature (quartz and K-feldspar) mineralogy.

more quartzose composition than sandstones of the Naknek Formation on the Iniskin Peninsula. The hydrocarbon-stained sandstone (33 $\mathrm{m}$ in the measured section) is friable with significant intergranular pores visible in hand specimen, indicating it has good to very good reservoir quality. It is not clear if other sandstones in the measured section possess similar reservoir quality. Commonly, sandstones exposed on the outcrop surface were friable and appeared to have intergranular porosity. However, when digging into the outcrop the sandstones were often fairly well lithified. While the porosity in the hydrocarbon-stained sandstone is undoubtedly real, the perceived good reservoir quality of other sandstones may result from surficial outcrop weathering. Detailed analysis of thin sections will help determine the actual reservoir quality of these sandstones. In any case, the presence of relatively quartzose Naknek sandstones is potentially of regional significance. The more mature mineralogy is less susceptible to zeolite cementation and is more likely to retain primary porosity on moderate to deep burial. These sandstones may have the potential to serve as conventional reservoirs.

\section{Kaguyak Formation}

Sandstones were examined from the type section of the Kaguyak Formation along the western shore of Shelikof Strait north of Hallo Bay (figs. 1, 12A, B, and 25; see also Wartes and others [A], this report). The sandstones ranged from veryfine- to medium-grained and were typically angular to subangular, moderately well sorted, well lithified, and contained greater than 50 percent dark grains, probably chert or volcanic rock fragments (VRFs). No appreciable porosity was noted in any of the samples examined. The sandstones are locally cut by igneous dikes that may be partially responsible for the poor reservoir quality. Additional outcrops should be examined to determine if the type section is representative of regional levels of reservoir quality.

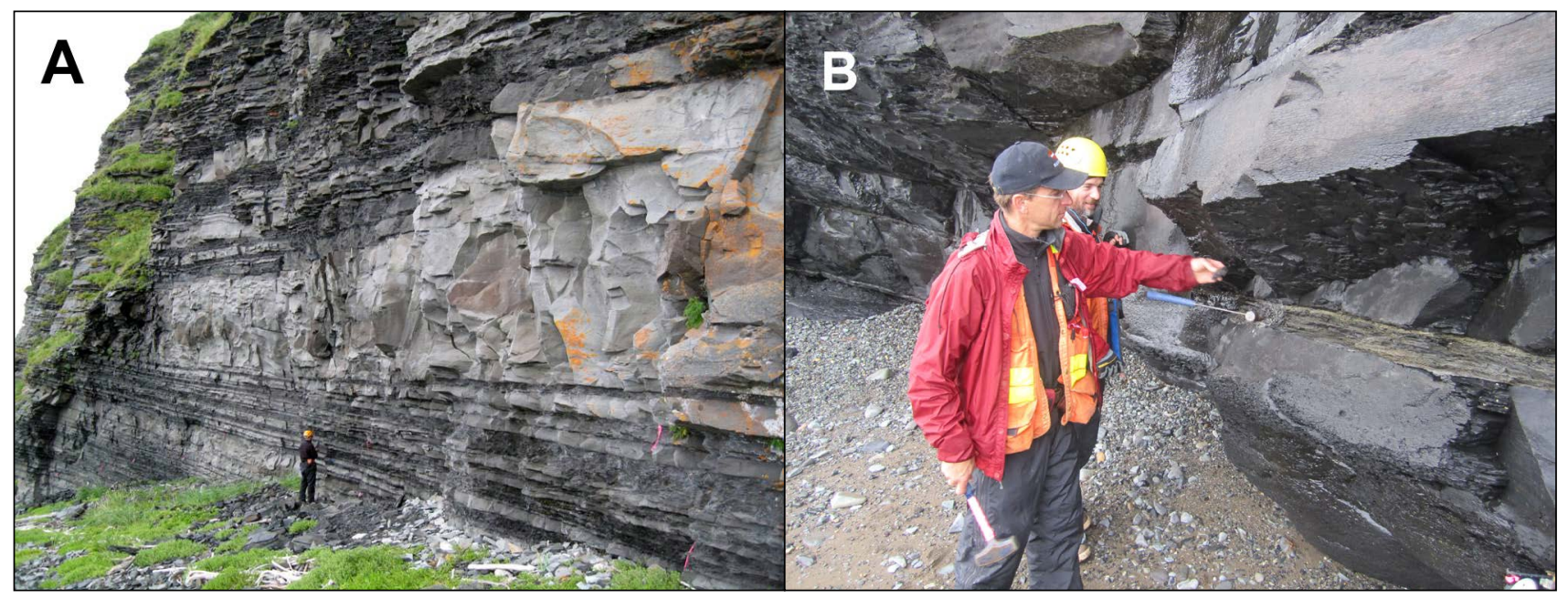

Figure 12. (A) Interbedded sandstones and mudstones exposed at the type section of the Kaguyak Formation north of Hallo Bay. (B) Outcrops of the Kaguyak Formation surveyed during summer 2012 are well indurated with overall poor reservoir quality. 